\title{
Skin test in drug eruption Five years experience at Dr. Cipto Mangunkusumo General Hospital, Jakarta
}

\author{
Retno Widowati Soebaryo, Tantien Nugrohowati, Evita Halim Effendi
}

\begin{abstract}
Abstrak
Pada setiap pemberian obat kepada pasien reaksi simpang obat harus selalu dipertimbangkan. Pajanan ulang dengan obat penyebab dapat menyebabkan erupsi obat menjadi lebih berat daripada bentuk klinis sebelumnya, bahkan dapat mengancam jiwa. Penelitian retrospektif yang dilaksanakan selama 5 tahun (1998 - 2002) ini bertujuan mengkaji peran uji kulit sebagai metode alternatif guna menemukan obat penyebab erupsi obat. Bentuk klinis erupsi obat menjadi perhatian khusus. Bentuk klinis tersering yang dijumpai ialah fixed drug eruption (FDE), urtikaria, erupsi eksematosa, erupsi eksantematosa, dan eritroderma. Uji kulit dilaksanakan pada 125 dari sejumlah 746 pasien dengan berbagai bentuk klinis erupsi obat, dan $34.4 \%$ memberi hasil positif. Pada beberapa kasus urtikaria dan FDE ringan dilakukan pula provokasi per-oral dengan perhatian khusus. Hasil penelitian menunjukkan bahwa uji kulit dapat dipergunakan sebagai metoda alternatif yang relatif aman dan mudah terhadap provokasi per-oral guna menemukan obat penyebab pada erupsi obat, terutama pada bentuk klinis berat. (Med J Indones 2004; 13: 81-5)
\end{abstract}

\begin{abstract}
Side effect of a drug should always considered by the physician in prescribing the drug for patients. Drug eruption could be very severe and re-exposure to traces of possible causative drugs may induce the same or even fatal clinical type of skin lesion. The aim of the study was to evaluate the role of skin test, an alternative in-vivo methods, in determining the cause of drug eruption. A retrospective study on results of skin test (patch and prick test) in drug eruption was conducted during 5 years period (1998-2002), with special interest on clinical type of lesion. The most prominent clinical type were fixed drug eruption(FDE), urticaria, eczematous eruption, exanthematous eruption, and erythroderma. Skin test was done on 125 out of 746 patients with drug eruption, and $34.4 \%$ gave positive results. In some mild cases of urticaria and FDE oral provocation test was done with special precaution. The results showed that skin test could be considered as an alternative, safe and relatively easy way to the oral challenge test to find the causative drug in drug eruption, especially the severe form. (Med J Indones 2004; 13: 81-5)
\end{abstract}

Keywords: skin test, drug eruption, cutaneous adverse drug reaction (CADR).

Drug eruption or cutaneous adverse drug eruption (CADR) must always consider in patient management. CADR are a frequent problem in dermatology, especially in finding the causative drug, due to multiple drug regimens frequently prescribe by the physician.

An allergic reaction involves immunological mechanism and the clinical manifestation are often thought to be combination of different Coombs and Gell type reactions. ${ }^{1}$

Allergy-Immunology Sub Department, Department of Dermatovenereology, Faculty of Medicine, University of Indonesia I Dr. Cipto Mangunkusumo General Hospital, Jakarta, Indonesia
Oral challenge is still the gold standard in investigating the cause of CADR. In severe cases of CADR performing an oral challenge test is dangerous and is not excepted from the ethical point. ${ }^{2}$ Skin testing with drug, as an alternative methods, has been one of the main interests during the past 10 to 15 years. $^{3}$ To find the causative drugs is not only important to the re-exposing of the drug in the future but also to the physician to find an alternative drug to be given to the patient. ${ }^{4}$

In sub-department of Allergy-Immunology, Department of Dermato-venereology, Faculty of Medicine, skin test was performed on different clinical type of CADR to find the causative drug. Five years $(1998-2002)$ evaluation of skin test results on different clinical type of CADR was presented. 


\section{METHODS}

A retrospective study of drug eruption was conducted on patients who underwent skin test during 1998 2002 at sub-department of Allergy Immunology, Department of Dermatovenereology, Faculty of Medicine, University of Indonesia / Dr. Cipto Mangunkusumo Hospital, Jakarta. A closed patch test was performed with the suspected drug on the back using Finn Chamber ${ }^{\circledR}$ on Scanpor ${ }^{\circledR}$ tape (Epitest, Tuusula, Finland). Reading was performed on day 2, day 3 , and day 4 . The result was reported based on ICDRG criteria. ${ }^{5,6}$ The concentration of the drug for patch test was made according to de Groot (1986). ${ }^{7}$ Negative patch test result, was followed by prick test with the suspected drug.

For prick test the drug was sequential diluted at $10^{-2}$ and $10^{-1}$. Reaction are considered positive when a wheal with diameter $3 \mathrm{~mm}$ larger than negative control ( $0.9 \%$ saline) is present 20 minutes later. Positive control was performed with histamine $(10 \mathrm{mg} / \mathrm{ml}){ }^{5}$

\section{RESULTS}

Seven hundred forty six (746) patients were diagnosed as drug eruption during the period of $1998-2002$. Fixed drug eruption (FDE) were the most common (21.99\%) clinical type found, followed by urticaria (11.80); eczematous eruption (10.72); exanthema eruption (7.51\%); and erythroderma (7.51\%) (Table 1).

Skin test were done in 125 patients and 43 (34.4\%) gave positive result. The 5 prominent positive patch test results were obtained from erythema multiforme $66.7 \%$, erythroderma $60 \%$, erythema $57.1 \%$, eczematous eruption $45.5 \%$, papular eruption $33.3 \%$. The 5 prominent positive SPT results were erythema $66.7 \%$, exanthematous eruption $50 \%$, erythroderma $42.9 \%$, urticaria $42.1 \%$, S-J syndr/TEN $37.5 \%$ as shown on Table 2.

Table 1. Diagnosis based on clinical presentation (10 most common)

\begin{tabular}{lccccccc}
\hline Clinical Diagnosis / year & $' 98$ & $' 99$ & $' 00$ & $' 01$ & $' 02$ & $\sum$ & $\%$ \\
\hline FDE & 17 & 34 & 40 & 34 & 39 & 164 & 21.99 \\
Urticaria & 18 & 23 & 16 & 23 & 8 & 88 & 11.80 \\
Eczematous eruption & 20 & 23 & 15 & 11 & 11 & 80 & 10.72 \\
Exanthema eruption & 6 & 7 & 9 & 9 & 25 & 56 & 7.51 \\
Erythroderma & 9 & 12 & 16 & 8 & 11 & 56 & 7.51 \\
S-J syndrome & 11 & 10 & 14 & 10 & 10 & 55 & 7.37 \\
Erythema multiforme & 8 & 12 & 16 & 8 & 11 & 55 & 7.37 \\
Acneiform eruption & 9 & 15 & 8 & 7 & 5 & 44 & 5.90 \\
Erythema & 2 & 4 & 10 & 4 & 8 & 28 & 3.75 \\
Papular eruption & 2 & 8 & 5 & 5 & 4 & 24 & 3.22 \\
\hline
\end{tabular}

Table 2. Result of skin test (according to 10 most common clinical type found)

\begin{tabular}{|c|c|c|c|c|c|c|}
\hline \multirow[t]{2}{*}{ Clinical Diagnosis } & \multicolumn{3}{|c|}{ Patch test } & \multicolumn{3}{|c|}{ Prick test } \\
\hline & $\sum$ & $+\mathrm{ve}$ & $\%$ & $\sum$ & $+\mathrm{ve}$ & $\%$ \\
\hline FDE & 39 & 11 & 28.2 & 14 & 4 & 28.6 \\
\hline Urticaria & 24 & 6 & 25.0 & 19 & 8 & 42.1 \\
\hline Eczematous eruption & 11 & 5 & 45.5 & 7 & 1 & 14.3 \\
\hline Exanthema eruption & 5 & 0 & 0 & 4 & 2 & 50.0 \\
\hline Erythroderma & 10 & 6 & 60.0 & 7 & 3 & 42.9 \\
\hline S-J syndrome /TEN & 14 & 4 & 28.6 & 8 & 3 & 37.5 \\
\hline Erythema multiforme & 6 & 4 & 66.7 & 5 & 1 & 20.0 \\
\hline Acneiform eruption & - & - & - & - & - & - \\
\hline Erythema & 7 & 4 & 57.1 & 6 & 4 & 66.7 \\
\hline Papular eruption & 3 & 1 & 33.3 & 0 & 0 & 0 \\
\hline Others & 6 & 0 & 0 & 6 & 2 & 33.3 \\
\hline
\end{tabular}


The most frequent drugs that give positive results on overall skin test are shown on Table 3.

Table 3. Most frequent causative drug found on skin test

\begin{tabular}{lccc}
\hline Drug & $\sum$ & $+\mathrm{ve}$ & $\%$ \\
\hline & & & \\
Paracetamol & 61 & 8 & 13.11 \\
Amoxycillin & 31 & 6 & 19.35 \\
Rifampicin & 27 & 5 & 18.52 \\
Metamizole sodium & 13 & 4 & 30.77 \\
\hline
\end{tabular}

Confirmation of the skin test with oral provocation test was conducted in several mild urticaria and FDE patients and the results are shown on Table 4.

Table 4. Confirmation of skin test to oral challenge

\begin{tabular}{lllc}
\hline Diagnosis & Patch test +ve & SPT+ve & Oral prov+ve \\
\hline Urticaria & Amoxycillin & & $1 / 2$ dose \\
Urticaria & Amoxycillin & & $1 / 4$ dose \\
Urticaria & & Paracetamol & 1 dose \\
Urticaria & & Piroxicam & 1 dose \\
FDE & Tetracyclin & & $1 / 4$ dose \\
\hline
\end{tabular}

History of atopy (personal, family or both) including asthma bronchiale, allergic rhinitis, and atopic dermatitis as one of the risk factor for CADR were included in the study with positive results of 369/697 $(52.9 \%)$. (Table 5)

Table 5. History of atopy

\begin{tabular}{lcccccc}
\hline Atopy/year & $' 98$ & $' 99$ & $' 00$ & $' 01$ & $' 02$ & $\sum$ \\
\hline Personal & 10 & 29 & 29 & 20 & 24 & 112 \\
Family & 8 & 28 & 29 & 23 & 19 & 107 \\
Both & 7 & 33 & 35 & 40 & 35 & 150 \\
None & 37 & 69 & 58 & 48 & 56 & 268 \\
Unknown & 3 & 13 & 18 & 11 & 15 & 60 \\
\hline$\sum$ & 65 & 172 & 169 & 142 & 149 & $697^{*}$ \\
\hline
\end{tabular}

\section{DISCUSSION}

To evaluate the cause of systemic drug eruption oral provocation test may provoked the same or even more worse reaction, and in severe cases it is not possible from the ethical point. ${ }^{2,8}$ Skin testing (patch test, skin prick test and intradermal test) with the suspected compound has been reported to be helpful in determining the cause of CADR and in studying the pathophysiological mechanism involved in these reaction. ${ }^{5}$ In performing skin test it should be remembered that serious adverse reaction could be provoked due to re-exposure to the possibly causative drug. ${ }^{4}$ In this study the most prominent clinical type found were fixed drug eruption (FDE), followed by urticaria, and eczematous eruption as presented in Table 1.

Patients with CADR were asks to conduct a skin test; 125 patients out of 746 patients with CADR responses. Positive results were obtained in 43 (34.4\%) patients.

Osawa reported a total positive patch test result of $31.5 \%$ conducted on several clinical type of CADR (Table 6)*. Effendi et al reported $23.68 \%$ positive patch test results. ${ }^{8}$ Our results, which consist of patch test and skin prick test, showed a higher percentage; slightly lower than reported by Soebaryo. ${ }^{10}$

Table 6. Patch test results ( $n=197$, according clinical Diagnosis) (Osawa et al J.Derm 1990;17:235-9)*

\begin{tabular}{lcc}
\hline Clinical Diagnosis & no.pos/no.patients & $\%+\mathrm{ve}$ \\
\hline Maculopapular eruption & $10 / 72$ & 13.9 \\
Erythema multiforme & $6 / 29$ & 20.7 \\
Erythroderma & $8 / 15$ & 53.3 \\
Eczematous eruption & $9 / 17$ & 52.9 \\
Lichenoid eruption & $2 / 11$ & 18.2 \\
Exanthema fixtum & $2 / 6$ & 33.3 \\
Others & $15 / 47$ & 31.9 \\
\hline Total & $62 / 197$ & 31.5 \\
\hline
\end{tabular}

*from ref. 9

Patch test is used to identify the causes of exanthematous and pustular drug eruption, FDE, Stevens-Johnsons syndrom (SJS), and toxic epidermal necrolysis (TEN). ${ }^{3}$ Theoretically patch testing would give a positive result if there is delayed hypersensitivity or there are sensitized $\mathrm{T}$ cells / memory $\mathrm{T}$ cells that become numerous in the most severely affected skin. $^{8,11}$

On Table 2 a high positive results of patch test were obtained on patients with eczematous eruption, erythroderma, erythema multiforme, and papular

* cited from ref. 9 
eruption. Patch test on FDE patients were done on the involved and un-involved skin lesion. ${ }^{12-14}$ In FDE the patch test result gave a higher positive result than the prick test, while in urticaria patients the positive prick test result is higher as expected concerning the underlying pathogenic mechanism. ${ }^{1}$ In this study the results of patch test on exanthematous eruption were negative and skin prick test followed the negative patch test showed $50 \%$ positive results; this proved that the clinical eruptions are a combination of the different Coombs and Gell reaction type. ${ }^{1}$ Other reason is the possibility of metabolite as the cause, which is difficult to trace. Ideally, skin test should be performed with the commercialized drug, and if possible the pure active products and excipient (filler). ${ }^{3}$ To performed test with pure active products is another constrained in our study.

The most frequent causative drug are antipyretic (paracetamol, metamizole), and antibiotic (amoxycillin, rifampicin). These drugs are commonly prescribed by the physician. Important skin manifestation of side effects of drugs is based partly on the data of clinical trials, national or international registered of harmful effects of drugs. Difficulties in deciding which side effects are important, eg severe reactions are regarded important even they occur seldom and exanthems subsiding in a few days are also listed important if they occur frequently. In case of newer drug data on side effects is usually sparse that the importance of skin manifestations is not yet established. ${ }^{15}$

In a mild form of CADR an oral provocation test were performed with a precaution for a severe reaction (Table 4). In urticaria patient with positive patch test results, oral provocation test with amoxycillin $1 / 4$ and $1 / 2$ dose gave a positive results. Full dose oral provocation with with paracetamol and piroxicam gave positive result in SPT positive patients. In FDE positive patch test patient oral provocation with tetracyclin $1 / 2$ dose gave positive result. These results support the role of skin testing in CADR as an alternative to oral provocation test. ${ }^{3-5,9}$

One of the risk factor for allergic drug eruption is atopy, including asthma bronchiale, allergic rhinitis, or atopic dermatitis. In this study we found that $52.9 \%$ of the respondent has history of atopy, either personal, family or both as seen in Table 7. Atopy was included in the history of CADR since mid of year '98 (total respondent were 697)

\section{CONCLUSION}

Skin test could detect the cause of CADR in $34.4 \%$ patients.Fixed drug eruption, urticaria and exanthematous eruption were the most common clinical manifestation of drug eruption. Atopic history was found in relative high percentage and could considered as the risk factor of CADR Paracetamol and amoxycilline were the most frequent cause of CADR that could be proven by skin test. Skin test could be used as an alternative for determining the causative drug in CADR, especially in the severe form.

\section{REFERENCES}

1. Alanko K, Hannuksela M. Mechanism in Drug Reaction. In: Skin Reaction to Drugs. Kauppinen K, Alanko K, Hannuksela M, Maibach HI, editors. London: CRC; 1998. p.17-24

2. Alanko K, Kauppinen K. Diagnosis of drug Eruptions: Clinical Evaluation and Drug Challenge. In: Skin Reaction to Drugs. Kauppinen K, Alanko K, Hannuksela M, Maibach HI, editors. London: CRC; 1998. p. 75-79

3. Hannuksela M. Skin testing in Drug Hypersensitivity. In: Skin Reaction to Drugs. Kauppinen K, Alanko K, Hannuksela M, Maibach HI, editors. London: CRC; 1998. p. $82-85$

4. Gerhardt T, Wollina U. Allergy testing in serious cutaneous drug reactions - harmful or beneficial ? Contact Dermatitis 1997;37:282-5.

5. Barbaud A, Goncalo M, Bruynzeel D, Bircher A. Guidelines for performing skin test with drug in investigation of cutaneous adverse drug reactions. Contact Dermatitis 2001;45:321-8.

6. Malten KE, Nater JP, Ketel WG. Patch testing guidelines. Nijmegen: Dekker and van de Vegt; 1976.

7. deGroot AC. Patch testing. Test concentration and vehicles for 2800 allergens. Amsterdam: Elsevier; 1986.

8. Effendi E, Hendragini, Soebaryo RW. Patch testing in drug eruption. Malaysian J Dermatol 1996:9;31-4.

9. Bruynzeel DP, Maibach HI. Patch testing in Systemic Drug eruptions. In: Skin Reaction to Drugs. Kauppinen K, Alanko K, Hannuksela M, Maibach HI, editors. London: CRC; 1998. p. 97-109.

10. Soebaryo, RW Role of skin testing in drug allergy. Presented at The World of Allergy - Leading the way. Bali,1999.

11. Barbaud A, Trechot P, Reichert-Penetrat S, Grane $1 \mathrm{~F}$, Schmutz JL. The usefulness of patch testing on the previously most severely affected site in a cutaneous adverse drug reaction to tetrazepam. Contact Dermatitis 2001: 44; 259-60

12. Bayazit EO, Gungor H. Trimethoprim-induced fixed drug eruption: positive topical provocation on previously involved and uninvolved skin. Contact Dermatitis 1997:39; 87-8. 
13. Rosina P, Chieregato C, Schena D. Fixed drug eruption from clarithromycin. Contact Dermatitis 1998:38; 105-22.

14. Lee, AY. Topical provocation in 31 cases of fixed drug eruption: change of causative drugs in 10 years. Contact Dermatitis 1998: 38; 258-60.
15. Hannuksela M, Alanko K, Kauppinen K. Drug causing Cutaneous Reactions. In: Skin Reaction to Drugs. Kauppinen K, Alanko K, Hannuksela M, Maibach HI, editors. London: CRC; 1998. p.151-63. 